\title{
The Russian Woman IN THE IMAginaRY OF THE FRIENDS AND ENEMIES OF THE SOVIET UNION (1905-1945) \\ La mujer rusa en el imaginario de los Amigos y Enemigos de la Unión Soviética (1905-1945)
}

Sofía Rodríguez López

\section{Universidad de Cádiz}

sofia.rodriguez@uca.es - https://orcid.org/0000-0002-3937-7564

\section{Fecha recepción 07.10.2018 / Fecha aceptación 21.01.2019}

\section{Resumen}

En este artículo abordaremos tanto un estado de la cuestión sobre el papel de las mujeres rusas en la Revolución de 1917, como la propaganda que circuló en España sobre su situación en el Estado comunista. En este sentido, veremos cuáles fueron las principales publicaciones, las afiliadas a la Asociación de Amigos de la Unión Soviética entre 1933 y 1938, así como sus vínculos personales con Rusia, o qué aspectos interesaban a nivel legislativo, laboral, familiar o sexual sobre lo que el imaginario entendía cómo «nueva mujer», "amor libre», etc., dentro de la dialéctica fascismo/antifascismo. Por otra parte, veremos cómo el bando franquis-

\section{Abstract}

In this article, we review the current knowledge on the role of Russian women in the Revolution of 1917 and the propaganda that circulated in Spain about their situation in the Communist State. This involves an analysis of the main publications, affiliated to the Association of Friends of the Soviet Union between 1933 and 1938, their personal links with Russia and the aspects of interest in legislative, labor, family and sexual areas regarding the imaginary's understanding of the «new woman», «free love», etc., within the dialectic fascism/antifascism. This is supplemented by an exploration of how Francoist supporters, the 
Monográfico ～La mujer rusa en el imaginario de los Amigos y Enemigos de la Unión Soviética (1905-1945)

ta, la dictadura después y especialmente la Sección Femenina de Falange se encargaron de denostar a esas «madres desnaturalizadas» tras el telón de acero y caricaturizarlas, al menos hasta el final de la Segunda Guerra Mundial, como representación de la Anti-España y la No-Mujer.

\section{Palabras clave}

Mujeres, Revolución, Propaganda, Amigos de la Unión Soviética, Antikomintern, España. dictatorship and especially the Feminine Section of the Phalange took it upon themselves to insult these «denatured mothers» behind the iron curtain, caricaturing them, at least until the end of the Second World War, as an Anti-Spain and No-Woman representation.

\section{Key words}

Women, Revolution, Propaganda, Friends of the Soviet Union, Antikomintern, Spain. 


\section{Introducción}

El papel de las mujeres en la Revolución Rusa está siendo cada vez más documentado gracias a historiadoras como Barbara Clements, Jane McDermid, Anna Hillyar o Moira Donald ${ }^{1}$. Lo que ha tenido menos éxito, como señala Kate Turton, es la integración de sus hallazgos en la narrativa general de 1917. Esto se debería, en parte, al escaso protagonismo de las bolcheviques en la elite del nuevo gobierno soviético, y a la tendencia persistente a historiar a las mujeres de forma independiente, de modo que los expertos en el periodo no recurren a dichas lecturas ${ }^{2}$.

Frente a los libros de propaganda de los años 30, Barbara Heldt fue una de las primeras en estudiar la tradición rusa de la prosa autobiográfica femenina ${ }^{3}$. Más recientemente, Cynthia Simmons y Nina Perlina han recorrido los archivos donde las mujeres anónimas del sitio de Leningrado depositaron sus diarios y memorias. Aunque éstas escribían cuando «sentían que podían contribuir a la esfera de la vida pública» como revolucionarias, presas políticas o conservadoras de la cultura, su posición habitual en los márgenes de la sociedad y en el ámbito de lo privado, hacía que se expresaran de una manera más abierta que los hombres, aunque ni ellas mismas fueran conscientes de la naturaleza de género de sus experien-

1. B. Clements, A History of Women in Russia: From Earliest Times to the Present, Indiana, 2012 y "Working-Class and Peasant Women in the Russian Revolution, 1917-1923", Signs, 8/2, 1982, 215-235.; J. McDermid y A. Hillyar, Revolutionary Women in Russia, 1870-1917: A Study in Collective Biography, Manchester, 2000 y Women and work in Russia, 1880-1930, London, 1998; M. Donald, 'What did you do in the Revolution, Mother?' Image, Myth and Prejudice in Western Writing on the Russian Revolution", Gender \& History, 7/1, 1995, 85-99.

2. Entre las investigaciones a cargo de mujeres: M.C. Burnet-Vigniel, "Bardina: Itinéraire d'une populiste, 1853-1883", Cahiers du Monde Russe, XVI, 3/4, 1975, 323-352 y Femmes russes dans le combat révolutionnaire, Paris, 1990; Z. Galili, "Women and the Russian Revolution", Dialectical Anthropology, 15, 2/3, 1990, 119-127; J. Lokaneeta, "Alexandra Kollontai and Marxist Feminism”, Economic and Political Weekly, 36/17, 2001, 1405-1412; B. Studer y R. Kramer, "Communism and feminism", Clio, 41 ("Real socialism" and the challenge of gender), 2015, 126-139. Entre las obras generales que sí han prestado atención al rol femenino durante la Gran Guerra y la revolución, encontramos: R.A. Wade. The Russian Revolution, 1917, Cambridge, 2001 o R. Stites et alii, Bolshevik Culture: Experiment and Order in Russian Revolution, Indiana, 1985.

3. B. Heldt, Terrible Perfection: Women and Russian Literature, Indiana, 1987. 
cias... «Algunas instituciones no pudieron proporcionarme heroínas, porque les restaban importancia a las auténticas y, en su lugar, proponían a sus protegidas» ${ }^{4}$.

Las bolcheviques "protegidas» asumieron esos roles que se reproducirían en todas las guerras: organización de las comunicaciones, la intendencia y el apoyo médico. Ya en el nuevo Estado soviético, sus funciones administrativas cubrirían las áreas típicamente «femeninas» del trabajo gubernamental: asistencia sanitaria, bienestar público y educación, como en el caso de Nadezhda Krupskaia, siendo muy escasas las nominadas como ella entre los Comisarios del Pueblo. Citaremos entre esa elite a Yakovleva, comisaria de Finanzas; Kalinina, secretaria del Comité Ejecutivo de la Región de Ivanovo; o las más jóvenes, Niurina, procuradora adjunta de la RSFSR (República Socialista Federativa Soviética de Rusia) o Chaburova, destacada en el movimiento sindical junto a cientos de presidentas de soviets de aldea, que en 1936 eran más de un tercio del total ${ }^{5}$.

Otras mujeres jugaron un papel importante en la oposición a los bolcheviques. A las soldados dirigidas por Maria Bochkareva, habríamos de unir la condesa Sofía Panina, adjunta del Ministerio de Educación y única mujer del Gobierno Provisional.

Kate Turton, por su parte, utiliza el «mito del sistema solar» para describir cómo se ha relatado históricamente la relación de Anna, Olga y Maria Ulianova con su hermano Vladimir Ilich Lenin. Su liderazgo en el nuevo régimen soviético hizo que la vida de las hermanas girase en torno a él, eclipsando la trayectoria individual de estas tres revolucionarias, que sobrevivieron más de una década entre la clandestinidad y el aparato del régimen.

De los seis hijos en la familia Ulianov, Anna era la niña mayor y, como universitaria, había estado involucrada en la actividad ilegal de su hermano Alexander, por lo que pudo instigar a Lenin, Olga y los dos hermanos menores, Maria y Dimitri, a unirse al movimiento revolucionario. Olga murió con 19 años, pero los restantes se convirtieron en miembros activos de los socialdemócratas y, más tarde, de la facción bolchevique. Después de 1917, Maria fue Secretaria Ejecutiva de Pravda, mientras que Anna trabajó primero para el Departamento para la Protección de la Infancia y después en Istpart, la Comisión de Historia de la Revolución de Octubre y el Partido Comunista Ruso. De hecho, tuvo un desacuerdo con Stalin sobre la biografía de Lenin, al no permitírsele publicar sus orígenes judíos ${ }^{6}$.

El trabajo de un revolucionario en el régimen zarista era peligroso y muchos argumentaron que debían permanecer solteros para no poner en riesgo a los familiares. Sin embargo, se tuvieron hijos antes y después de comprometerse políticamente. A veces los padres, y a menudo la madre, se retiraban de la actividad para cuidar de sus pequeños o que lo hicieran sus tíos, abuelos o camaradas, en caso de ser arrestados. Pero en otras ocasiones conciliaban

4. C. Simmons y N. Perlina, Escritos de mujeres desde el sitio de Leningrado, Segovia, 2014, 21-23, 102, 156.

5. "Toda cocinera debe ser capaz de gobernar el Estado", Rusia de Hoy, 2, marzo-abril 1936 y Solomin, La emancipación de la mujer en la U.R.S.S., Madrid, 1938, 4.

6. K. Turton, Forgotten Lives: the role of Lenin's sisters in the Russian Revolution, 1864-1937, Basingstocke, 2007 y S. Cooch, "Interview: Women in the Revolution", Revolutionary socialism in the 21st Century, 08/03/2017 [Consulta 30/06/2018 en https://www.rs21.org.uk/2017/03/08/interview-women-in-the-revolution/]. 
su trabajo con sus deberes como progenitores/as. De tal modo que algunas imprentas escondidas en casas particulares operaban sólo de noche y una vez que los niños estaban dormidos.

Este ensayo no aborda tanto los escritos personales de estas mujeres y sus hijos, como el mensaje que se transmitía acerca de sus trayectorias políticas y vitales. Conquistas relatadas primero con miedo o expectación por los contemporáneos de la Restauración borbónica o Primo de Rivera; con entusiasmo después, por algunos republicanos antifascistas y Amigos de la Unión Soviética, y con absoluto desprecio por la dictadura franquista.

Con ello queremos poner en valor la proyección internacional del icono de la mujer revolucionaria, socialista, "roja”... por su carácter absolutamente transgresor, y mostrar cómo fue recibido en otros contextos políticos que estaban sufriendo su propia catarsis social en el periodo de entreguerras.

En España hay ya buenos trabajos sobre la influencia de la marea bolchevique, pero no una apelación directa a las mujeres como la que nos proponemos aquí, a partir de un análisis bibliográfico y prosopográfico ${ }^{7}$. Para ello acudiremos a las investigaciones realizadas durante los últimos cuarenta años en el mundo anglosajón y por académicas rusas. No obstante, son las publicaciones coetáneas a los acontecimientos, empleadas como propaganda o cordón sanitario, las que fundamentan nuestra hipótesis de partida: que la subversión de los roles de género se coló en las agendas políticas de las democracias occidentales, en pleno ascenso y caída, como una evidencia, un temor o una esperanza, más allá de la identidad nacional y de la conquista del poder por la clase obrera.

\section{Las revolucionarias rusas}

La tesis de Anna Hillyar está dedicada a las vidas de mujeres revolucionarias entre 18701889, 1890-1904, y 1905-1917 respectivamente, comparando sus hallazgos con los estudios sobre las bolcheviques de Barbara Evans Clements y las socialdemócratas de Beatie Fieseler. Sus análisis demuestran que su participación fue más generalizada en todo el movimiento de lo que se había reconocido hasta los años 90 del siglo XX, y que obreras e intelectuales pensaron y actuaron de forma independiente, consagrando modelos a seguir.

Dentro de la historiografía, predominan las obras dedicadas a unas pocas líderes del Partido Bolchevique, y entre las publicaciones generalistas se ha introducido la perspectiva de género sólo para constatar la escasa presencia femenina en la Revolución, que se conceptualiza casi sin su participación. Pues bien, las purgas de la década de 1930 privaron de libertad a miles de ellas y se aseguraron luego de que sus nombres desaparecieran de la historia.

7. C. Forcadell, "Impacto de la I Guerra Mundial y de la Revolución de Octubre en el movimiento obrero español", Contribuciones a la historia del PCE, FIM, 2004, 63-72; C.J. Almuiña, "La imagen de la revolución rusa en España (1917)", Investigaciones históricas: Época moderna y contemporánea, 17, 1997, 207-218; "La imagen de la Revolución rusa en España: amplificación y permanencias años veinte-noventa del siglo XX", Actas del XVI Congreso de la Asociación Internacional de Hispanistas, Vol. 2, Madrid, 2010 (CD).

8. B. Clements, Bolshevik Women, Cambridge, 1997 y B. Fieseler, "The Making of Russian Female Social Democrats, 1890-1917”, International Review of Social History, 34, 1989. 
Según Hillyar, incluso los héroes reconocidos oficialmente parecen desprovistos de alma, de ahí su interés por trazar un perfil de la rusa revolucionaria, que servirá para contrastarlo con el cliché que llegó a España, entre sus hagiógrafos y detractores?.

Geográficamente, los orígenes de estas protagonistas son extremadamente diversos y representativos del Estado ruso: la mayoría provenía de la Rusia europea y Ucrania, junto a un cuerpo sustancial de Polonia, el Cáucaso, Siberia y los Estados bálticos. Por ejemplo, Evgeniia Adamovich de la provincia de Poltava, Ekaterina Aleksandrova de Georgia, Nina Aladzhalova nació en Azerbaiyán, Inessa Armand en París, Liubov’ Aksel' rod era oriunda de la provincia de Vilnius, Aleksandra Kollontai nació en Moscú, Nadezhda Krupskaia en San Petersburgo y Konkordiia Samoilova en Irkutsk. Los batallones de mujeres se extendieron por ciudades como Saratov, Tambov, Mariupul, Ekaterinburg, Kiev, Tashkent, Ekaterinodar, Odessa, Minsk, Pskov, Riga y Ufa. Las únicas provincias ausentes serían las del Asia Central musulmana, sin embargo, la mayoría de los estudios de la Revolución de 1917 se centran en la capital, Petrogrado, pese a ser poco representativa del inmenso Imperio zarista ${ }^{10}$.

Respecto a la edad, las revoliutsionerki se unieron al movimiento en su adolescencia o primeros veinte años. El lugar de iniciación para las mujeres de la intelligentsia era su gimnasio (instituto de enseñanzas medias) o cursos superiores, mientras que para las trabajadoras era la fábrica y el hogar, cada vez más importante, no solo en la configuración de sus creencias, sino también en su participación directa en el trabajo clandestino.

El patrón de sus orígenes sociales muestra cada vez más mujeres de clase obrera y campesinas. Un análisis de los bolcheviques que se unieron a esta facción del Partido Obrero Socialdemócrata entre 1905 y 1922, apunta un 60\% de intelectuales y un $28 \%$ de trabajadoras. Entre 1914 y 1916, el porcentaje de mujeres militantes comenzó a crecer hasta alcanzar el $45.7 \%$ y con el recrudecimiento del movimiento obrero en 1912-13, la proporción femenina en la contratación total alcanzó el 59.2\%. Al mismo tiempo cayó el número de miembros de la intelligentsia y empleadas de alto y medio rango. Así, entre aquellas que se unieron durante la Primera Guerra Mundial constituyeron el 24.6\%, aunque las campesinas eran solo el 1.8\%.

No solo la gran mayoría de la población era rural, sino que la occidentalización de Pedro «el Grande» en cuanto a la relación entre los sexos, no se conocía ni había llegado a los confines del Imperio. Sólo el desarrollo económico de finales del siglo XIX trajo cambios a las vidas de las mujeres rusas. En su estudio del campesinado en 1917, Graeme Gill vio dos revoluciones, una en el campo y la otra en Petrogrado. Lo primero sería una protesta tradicional contra la Rusia privilegiada, en la que la única preocupación de los labradores era que quien estuviera en el poder accediera a sus demandas. Orlando Figes confirma la conclusión de Gill y acepta que el campesinado fue decisivo para destruir la base política y militar del viejo orden, aunque sin cambiar su estilo de vida agnaticio y androcéntrico. De modo que,

9. A. Hillyar, Revolutionary Women in Russia, 1870-1917: A Prosopographical Study, Southampton, 1999.

10. J. McDermid y A. Hillyar, Midwives of the Revolution: Female Bolsheviks and women workers in 1917, London, 1999. 
aunque las mujeres urbanas remaran en el mismo sentido que los hombres, las campesinas ni siquiera aprovecharon su derecho a voto en las elecciones de mayo de $1917^{11}$.

El estudio de Donald Raleigh de la ciudad de Saratov revela que, como en Petrogrado, la Gran Guerra tuvo un profundo impacto de «feminización» entre la población. Mientras que antes de 1914 había 102 mujeres por cada 100 hombres, dos años después eran 121 y, para 1917, el 30.7\% de todos los hogares en el campo carecía de mano de obra masculina. En 1915 las huelgas aumentaron en esta ciudad pequeña y poco industrializada, que aceptó rápidamente la caída del zarismo y contempló cómo se formaba un departamento especializado en reclutar mujeres de clase trabajadora. Como en Petrogrado, la mayoría se concentraban en el sector servicios, aunque en 1917 casi 200.000 estaban ocupadas en talleres textiles y de calzado para las tropas, así como el procesamiento de productos químicos, tabaco y alimentos. Éstas se sentían cada vez más atraídas por el radicalismo de los bolcheviques, aunque eso no implicara que abandonasen la cultura patriarcal del campo del Volga ${ }^{12}$.

La formación de estas mujeres estaba directamente relacionada con sus orígenes sociales. Trabajadoras y campesinas tenían el nivel más bajo, frente a una cultivada nobleza. Sin embargo, la mayoría de las revolucionarias prestaron gran atención a su educación, tratando de elevarla a través de círculos de estudio para alfabetizarse. Nina Tret'iakova trabajó como maestra hasta que en 1912 se unió al RSDRP (Rossiiskaia Sotsial-Demokraticheskaia Rabochaia Partiia) y se ocupó de una imprenta clandestina en Siberia, donde fue detenida hasta 1915. Desde entonces, sería directora de biblioteca y una escuela dominical, y en 1916 asistió a los Cursos Superiores para Mujeres de Moscú.

Aunque las mujeres de clases altas disponían de mayores oportunidades, no siempre las aprovecharon. Alexandra Kollontai tuvo una tutora particular porque sus padres no le permitieron ir al Gimnasio por miedo a la influencia negativa de «elementos indeseables». Tampoco la dejaron matricularse en los cursos Bestuzhev de donde, desde 1878 y durante cuarenta años, salieron las principales revolucionarias y feministas rusas, de origen urbano, como Nadezhda Stasova, Anna Filosofova, Mariia Trubnikova y Evgeniia Konradi, quien luchó incansablemente por el derecho de las mujeres a la educación superior.

Por otra parte, no pocas revolucionarias vincularon su vida profesional a la enseñanza o la medicina, como un privilegio del que tantas estaban privadas y a través del cual transmitir su ideología. Entre las más de 40 ocupaciones registradas por Hylliar se incluirían las de: actriz, encuadernadora, cajeras, químicas, zapatera, cocinera, dentista, médicas, enfermeras, servicio doméstico, obreras de la confitería, metal, tabaco o textil; periodistas, lavanderas, bibliotecarias, modistas, oficinistas, telefonistas, conductoras de tranvías, etc ${ }^{13}$.

11. G. Gill, Politics in the Russian Regions, London, 2007, 204-213 y O. Figes, La Revolución Rusa (18911924), Barcelona, 2010 [1996]. Sobre las diferencias regionales rusas: El baile de Natacha. Una historia cultural rusa, Barcelona, 2006 y S. Badcock, LG. Novikova, A. Lindenmeyr, C. Read, P. Waldron, Russia's Home Front in War and Revolution, 1914-22: Russian Revolution in Regional Perspective, Indiana, 2015.

12. D.J. Raleigh, Revolution on the Volga: 1917 in Saratov, Ithaca, NY, 1986, 29, 44.

13. A. Hillyar, Revolutionary Women in Russia, 1870-1917..., op. cit, 148. 
Pero la vida revolucionaria se había convertido no sólo en una causa, sino en una ocupación a tiempo completo para muchas mujeres, sobre todo de clase media y alta, que no necesitaban recurrir al empleo remunerado. Las trabajadoras no dispusieron de tantos fondos como los hombres del Partido Obrero Socialdemócrata para apoyarlas en los paros causados por su actividad política. Cuando fueron despedidas de sus fábricas tuvieron que mudarse a los suburbios y cambiar de trabajo por puestos peor pagados, como les sucedió a las obreras textiles Balashova y Golubeva, pertenecientes al mismo grupo de Ivanovo en 1907, o Anna Stepanova, que perdió su puesto en una fábrica de tubos de Voronezh por participar en las huelgas de 1915-1916.

La «doble carga» se incrementaba en el caso de las revolucionarias con marido e hijos. Los estudios de caso muestran una abrumadora mayoría casada con sus compañeros de armas, independientemente de su origen social y, a menudo, pese a la oposición familiar. Si bien la impresión es que los matrimonios de los revolucionarios eran más igualitarios, no existen evidencias para cuestionar cualquiera de los roles de género o sexuales tradicionales. Según Kollontai, ella se casó contra la voluntad de sus padres, y es que los matrimonios arreglados no eran sólo un fenómeno cultural de «los de arriba», sino que también encubrían actividades clandestinas. De hecho, la relación entre Krupskaia y Lenin comenzó cuando los bolcheviques la nombraron su "prometida», para que él pudiera recibir visitas durante su exilio en Siberia.

Las familias desempeñaron un papel importante en el apoyo a sus actividades, habiéndose documentado numerosas cartas de ayuda entre los socialdemócratas, como las madres de Eva Broido, Nadezhda Krupskaia, Elena Stasova, o los citados Ulianovs. Después estarían las madres revolucionarias sin nombre, conocidas como «tipo Gorky» por su novela.

La importancia de la conexión familiar también se demuestra en la gran cantidad de hermanos que participaron en actividades radicales, igual que hemos documentado en España, tanto con las milicianas y propagandistas antifascistas, como entre las afiliadas a Falange ${ }^{14}$. La documentación judicial es reveladora al respecto, con un patrón de hermandad revolucionaria que continuó hasta la Revolución de Octubre. Los círculos obreros desempeñaron un papel similar entre las trabajadoras, a veces influenciadas por sus esposos, aunque la literatura las retratara como analfabetas, atrasadas y reprimidas.

Una vez en el movimiento, las mujeres se involucraron a todos los niveles, aunque algunos autores las hayan considerado insignificantes: desde el momento en que permitieron que sus hogares fueran utilizados como zona franca, hasta la organización de encuentros por ellas mismas. Esa guerra pasiva o «sin armas», como la denomina Anna Bravo, es la misma que libraron tantas mujeres de otras latitudes y procesos revolucionarios: custodia de fugitivos, literatura, munición; agitación y propaganda; incitaciones a la huelga; labores técnicas en los registros, finanzas y comunicaciones, y así hasta el liderazgo teórico ${ }^{15}$.

14. S. Rodríguez, Mujeres en guerra. Almería, 1936-1939, Sevilla, 2003 y El patio de la cárcel, Sevilla, 2010.

15. A. Bravo, "Mujeres y Segunda Guerra Mundial: estrategias cotidianas, resistencia civil y problemas de interpretación", en M. Nash y S. Tavera, Las mujeres y las guerras Barcelona, 2003 y también A. Bravo y A. M. Bruzzone, In guerra senza armi. Storie di donne 1940-1945, Roma-Bari, 1995. 
La mayoría de estudios parte de la suposición subyacente de que la actitud de los bolcheviques era de condescendencia y descuido hacia las trabajadoras. Y es que la formación de la sección femenina del Partido Obrero Socialdemócrata entre la Revolución de 1905 y el final de la Guerra Civil en 1920, se desarrolló como resultado de su propia iniciativa. Solo Kollontai y unas pocas mujeres vieron la necesidad de organizarlas, dejando de ser consideradas un lastre para el movimiento obrero, por subestimar una capacidad de trabajo que continuó a pesar de la supresión de la revista Rabotnitsa («Trabajadora») en 1914 y su postura antibélica.

Mencheviques y socialrevolucionarios (SR) tampoco les prestaron mucha atención, ya que, si bien conocían las huelgas del sector servicios y las protestas femeninas por factores materiales, no lograron comprender que se estaba alimentando su conciencia política. Diane Koenker sugiere que, mientras los bolcheviques se concentraban en la juventud y los obreros inexpertos, las mujeres y sus camaradas mayores y experimentados tendieron a apoyar a los mencheviques en la Duma provincial, porque un partido moderado las haría sentirse más cómodas, pese a su incapacidad para atraerse a los campesinos, soldados y trabajadores ${ }^{16}$.

No obstante, en el quinto congreso del RSDRP las delegadas bolcheviques ya superaron a las mencheviques de cinco a una, aunque pocas revoliutsionerki entraron en la elite, permaneciendo la mayoría como agitadoras de base o en puestos de secretaria que, en la clandestinidad política, eran cruciales para la efectividad organizativa. Parece factible entonces la tesis de Hylliar: la subestimación femenina se debería a que sólo una minoría pudieron convertirse en profesionales, debido a su posición social y responsabilidades domésticas ${ }^{17}$.

Los opositores a la Revolución de Febrero describieron el ambiente inicial en Petrogrado como un motín apolítico protagonizado por mujeres hambrientas y niños que exigían pan y arenques, mientras destrozaban los tranvías y saqueaban pequeñas tiendas. En lugar de obedecer ciegamente a los oficiales para aplastar a las multitudes rebeldes, las tropas en Petrogrado escucharon los argumentos de las huelguistas hasta unirse a ellas. Pero, según la visión más tradicional de la historia, sólo la intervención masculina de obreros, soldados y políticos, convertirían esos días de febrero en la revolución que derrocó al zar ${ }^{18}$.

En 1917 había una profunda creencia entre los hombres revolucionarios de que las mujeres eran más atrasadas, conservadoras y menos propensas a abrazar la reforma social; sin embargo, una y otra vez ellas demostraron su interés por una política que mejorara sus vidas, dando como resultado grandes logros, aunque vulnerables a la contrarreforma.

Los bolcheviques sí que pusieron especial empeño en reclutar trabajadoras, haciendo que la revolución no fuera exclusivamente masculina. De modo que, tanto en las fábricas como en la prensa, encontramos figuras tan relevantes como Inesa Armand, clave para el

16. D. Koenker y W. Rosenberg, Strikes and Revolution in Russia, 1917. Princeton, NJ, 1989.

17. A. Hillyar, Revolutionary Women in Russia, 1870-1917... op.cit, 158-161.

18. J. McDermid y A. Hillyar, Midwives... op.cit, 188. La “cuestión del pan” en: O. Figes, La Revolución... 355.

Revista de historiografía 31, 2019, pp. 115-144 
establecimiento de Rabotnitsa en 1917, así como en la puesta en marcha de Comisiones de Agitación y Propaganda en Moscú, como las que Kollontai promovió en Petrogrado ${ }^{19}$.

Respecto a su actitud ante la I Guerra mundial, Konkordiá Samoilova insistió en 1920 en que esta experiencia tuvo un impacto más profundo en las mujeres que el hambre y el frío. El conflicto militar había sido tan costoso en vidas que abrió sus ojos sobre la opresión del sistema político encabezado por la aristocracia y los grandes capitalistas, haciendo que miles de ellas combatieran en las trincheras. Después de algunas semanas de entrenamiento, el Batallón de la Muerte de Mujeres partió hacia el frente oriental. Miles de residentes de San Petersburgo se reunieron en la estación de tren para ver a las mujeres irse a la guerra. El éxito de la «Ofensiva Kerensky» determinaría el destino del Gobierno Provisional, comprometido con los aliados, mientras que los bolcheviques de Lenin prometieron «paz, tierra y pan ${ }^{20}$.

En cuanto a la Revolución de Octubre, las mujeres de toda Rusia colaboraron con menos protagonismo que en la de Febrero. Pese a la alta participación de hasta un $70 \%$ en las elecciones a la Asamblea Constituyente, no hubo marchas, ni convocaron a los trabajadores y tampoco apelaron a los soldados para que no disparasen contra la multitud. Esto se explicaría por las diferentes naturalezas de ambas revoluciones, con un mayor respaldo popular en el primer caso y el liderazgo del proto Partido Comunista en el segundo. Hillyar y McDermid se preguntan por qué las mujeres tampoco aparecen en los análisis de los ocho meses que transcurren entre las dos oleadas de 1917. La explicación sería que no jugaron un papel prominente en la llegada de los bolcheviques al poder, de modo que los historiadores han otorgado más importancia a la forma en que el Estado comunista las integró a partir de 1920.

En cualquier caso, los hechos demuestran que no fue así. La reducción en casi un tercio del salario medio de los trabajadores no cualificados -con mayoría femenina- en junio de 1917, haría que éstas comenzaran a ver a los mencheviques como traidores a la clase obrera y a la propia revolución que ellos habían iniciado. De modo que, frente a quienes dan todo el protagonismo a los técnicos y estajanovistas a partir de mayo, las investigaciones han demostrado que las bolcheviques estuvieron en todas las movilizaciones.

Había mucho por hacer. En un congreso de campesinos pobres celebrado poco después de octubre, Zinoviev preguntó por qué todos los delegados eran hombres y le respondieron que no lo consideraron un lugar apropiado para la mujer. A pesar de las voces en contra, aún era palpable la desconfianza bolchevique a su conducta contrarrevolucionaria, algo que recuerda el miedo de los republicanos españoles al sufragio femenino en 1933.

Pero desde el comienzo de la Guerra Civil en 1918, muchas soviéticas hicieron uso de sus habilidades domésticas para el nuevo esfuerzo bélico: buscar comida y combustible para sus familias y las fábricas en funcionamiento; asegurar las provisiones militares; cuidar de los heridos, refugiados y niños abandonados, así como de los hombres y mujeres del frente.

19. A. Rowley, "Spreading the Bolshevik Message? Soviet Regional Periodicals for Women, 1917-1941", Canadian Slavonic Papers. Revue Canadienne des Slavistes, 47, 1/2, 2005, 111-126.

20. C. Harris, “The Women Warriors of the Russian Revolution”, Smithsonian.com, 28/04/2017. [Consulta on line 30/06/2018, https://www.smithsonianmag.com/history/women-warriors-russian-revolution180963067/\#ZbYwaEcm8SmuEZ91.99] 
Aunque pocas permanecieron en el Ejército Rojo después de 1920, el régimen victorioso esperaba que no solo cumplieran el papel tradicional de ama de casa y madres, sino que tomaran parte activa en la vida pública como mujeres «nuevas». Lenin propuso entonces que la política se acercara a las masas y los oprimidos, de modo que «hasta una cocinera pudiera dirigir el Estado $»^{21}$. Se crearía para ello un Departamento Femenino o Zhenotdel, encargado de su formación política contra los prejuicios de sus camaradas. Como ha explicado Novlkova, «cada tres o seis meses los comités de las fábricas y los soviets de las aldeas elegían una delegada que llevaba en la cabeza un pañuelo rojo como signo de poder» ${ }^{22}$.

La Administración enviaría también delegadas a juzgados y oficinas, donde aprendían el oficio para regresar a sus núcleos de origen y enseñar al resto de mujeres, aunque esto no consolidara cuadros profesionales. Asimismo, el Zhenotdel puso en marcha populosas campañas de concienciación que en las repúblicas musulmanas llevó a algunas activistas a despojarse del hijab y sentarse con las occidentales, pese a las amenazas.

En su estudio del Zhenotdel, Elizabeth Wood sostiene que significó una revolución feminista, aunque el Partido Comunista de Rusia también encontró en ellas algunas aliadas para perpetuar la división sexual del trabajo. El argumento es que los revolucionarios entendieron el orden político y la construcción del Estado comunista en términos de género, y el importante papel de las mujeres en 1917 no significó que ellas actuaran en desacuerdo con esas definiciones. Pero las soviéticas tomaron acción directa en los acontecimientos sin esperar a que les dijeran qué hacer o cómo hacerlo, y desafiaron a los hombres sin esperar a que las moldearan ${ }^{23}$.

El Primer Congreso de la Mujer Trabajadora celebrado en 1918 y liderado por Clara Zetkin, inspiró al primer gobierno bolchevique para instaurar la Ley soviética sobre el Matrimonio, la Familia y la Tutela. Ésta garantizaba: la igualdad jurídica entre los sexos, la equiparación salarial, el permiso de maternidad, la legalización del aborto y el divorcio, así como la abolición del estatus de hijos naturales. Se implantaba la coeducación y el derecho total de las rusas a la escolarización, el trabajo, el voto y los órganos de gobierno. Finalmente, para acabar con la «esclavitud doméstica», el Estado se haría cargo de socializar las tareas del hogar y el cuidado infantil, creándose guarderías, lavanderías y comedores comunales.

Un 8 de marzo pero de 1930, tras iniciar la colectivización forzosa de la agricultura, el Zhenotdel fue abolido por Stalin, alegando que había logrado sus objetivos y no era necesario.

21. “Toda cocinera debe ser capaz de gobernar el Estado", Rusia de Hoy, 2, marzo-abril 1936.

22. O. Novlkova, "Rusia, 1917. La revolución del pensamiento, la cultura y las emociones”, Nuestra Historia, 4, 2017, 21-42 y R. Stites, “Zhenotdel: Bolshevism and Russian Women, 1917-1930”, Russian History, $3 / 2,1976,174-193$.

23. E.A. Wood, The Baba and the Comrade. Gender and Politics in Revolutionary Russia. Bloomington, 1997. 


\section{Las revolucionarias españolas}

Las primeras asociaciones de mujeres trabajadoras surgidas en España se mirarían muy pronto en el espejo de las soviéticas, aunque tuvieron en el anarquismo una potencia inigualada, que sólo podemos comparar a la de Italia o la propia Rusia pre-revolucionaria. Gregorio Marañón escribió que «anarquismo y sindicalismo eran la expresión más auténtica de la psicología revolucionaria española», y es que las condiciones objetivas para la difusión de sus ideas eran mejores que para las socialistas, dada su simplicidad ideológica en un país en el que el analfabetismo eran un fenómeno feminizado y arraigado entre el proletariado ${ }^{24}$.

La Federación de Trabajadores de la Región Española se reuniría en 1889 en un congreso en el que ya tuvieron parte activa las oradoras sevillanas, llevando a cabo un examen sobre la jornada de ocho horas y la esclavitud que pesaba sobre ellas. La emancipación de la mujer no podía concebirse entonces sin la de la clase trabajadora, aunque en comparación con las demás tendencias de la izquierda española, fueron los anarquistas quienes dedicaron mayor atención a la hegemonía cultural del hombre y la discriminación en la enseñanza ${ }^{25}$.

Desde la aparición de las teorías de Bakunin, fueron numerosas las españolas que se sintieron atraídas por su programa. Destacó Teresa Mañé que, como maestra criada en una familia acomodada, regentó una escuela librepensadora hasta que fundó con Juan Montseny en Madrid La Revista Blanca (1898), donde colaboraría la propia Louise Michel.

Contemporánea suya fue la tejedora Teresa Claramunt, considerada la primera revolucionaria española, con mítines de propaganda sobre la «enseñanza permanente» de las obreras, como el de Congreso de Sabadell de 1884. A partir de entonces participaría en todas las acciones del movimiento obrero en Aragón y Andalucía, sufriendo innumerables detenciones y destierros en Portugal y Francia, donde escribió una obra feminista: La mujer. Consideraciones sobre su estado ante las prerrogativas del hombre ${ }^{26}$.

Las anarquistas españolas estarían presentes desde entonces en todos los focos de la lucha obrera. En 1904, cuando se declaró en Zaragoza la huelga general en solidaridad con los presos de Cataluña; en 1905, con los carpinteros; en 1906, con los mineros bilbaínos; en 1910 como apoyo a los mineros de Vizcaya, y en 1911 frente a la guerra de Marruecos. De hecho, ese año tuvo lugar el proceso contra Claramut, la maestra Antonia Maymón, Josefa López y Antonia Trigo, que cobijó en su casa a quienes se enfrentaron a la fuerza armada.

Entretanto, en Madrid y Barcelona destacó la aparición del colectivo «Damas Rojas», vinculado al republicanismo radical y que tanta importancia tuvo durante la Semana Trágica, como un grupo «parcialmente transgresor» y con reivindicaciones propias en favor de la conquista de derechos políticos y sociales. También en Bilbao, tuvo especial relieve la incorporación de las emakumes a la militancia socialista y radical de la primera década del siglo XX, dentro del proceso de modernización que experimentaron ambas formaciones. Pero fueron las huelguistas de la Agrupación Femenina Socialista de Madrid las que mayor

24. M. Buenacasa, El movimiento obrero español (1886-1926), Madrid, 1977.

25. M. Nash, Mujer y movimiento obrero en España (1931-1939), Barcelona, 1981, 21-28.

26. C. Alcalde, La mujer en la guerra civil española, Madrid, 1976, 180. 
prestigio alcanzaron desde 1906, recibiendo solicitudes para fundar otros grupos en más de 30 localidades y manteniendo contactos con sus homólogas europeas y latinoamericanas. No obstante, cuando Clara Zetkin les reclamó una delegada para el III Congreso Internacional de Mujeres Socialistas, tuvieron que declinar la invitación ante la escasez de recursos y su desconocimiento de idiomas, proponiendo a algún compañero que las representase ${ }^{27}$.

Las mujeres participaron también activamente en las luchas y motines que entre 1916 y 1917 se desencadenaron en el campo andaluz, y en las cuales menudearon los incidentes con la Guardia Civil o grupos armados de la patronal. Varias de ellas fueron víctimas del «pistolerismo» y la represión, por reclamar el aumento de los jornales, la expulsión de los trabajadores forasteros, o la colocación de los parados y la abolición del destajo... como se hacía en Moscú o Petrogrado. Pero, como dice Romero Salvadó, «España no era Rusia» ${ }^{28}$.

Ni siquiera la unidad sindical de UGT-CNT en los preparativos de una huelga general que derrocara al régimen de la Restauración, pudo acabar con la monarquía de Alfonso XIII y su pretorianismo militar. Si el cataclismo bélico fue lo que destruyó la estructura socioeconómica zarista, dividiendo a su clase dirigente y a las fuerzas armadas, la neutralidad española y sus envíos ilegales de armas no hicieron sino incrementar el poderío industrial catalán y el regionalismo de la Lliga. No sufrió una sangría humana, pero tampoco pudo evitar la crisis económica y la radicalización del movimiento obrero, así como la polarización social y política por esa neutralidad (Romanones/Dato), lo que daría paso al ciclo de $1917^{29}$.

En el «verano caliente» de ese año, diversos periódicos de provincias como El Liberal de Murcia que, desde la cómoda posición española seguían el desarrollo de la Guerra Mundial y la Revolución Rusa, subrayaban al carácter transgresor de Sonia Morova o las milicianas del Batallón de la Muerte, y algunos liberales como Joaquín Dicenta o Luis de Zulueta apelaban a la normalización de la utopía, representada por los «Comités rusos de muchachos de veinte años y mujeres escapadas de Siberia» ${ }^{30}$.

Ese «Batallón de la Muerte» fue constituido por una campesina que, huyendo de su matrimonio, solicitó alistarse en el ejército imperial al zar Nicolás II, en noviembre de 1914. Sus compañeros se mofaron y abusaron de ella hasta que demostró su valía en el campo de batalla, donde fue herida dos veces. En mayo de 1917 la guerra se había prolongado, con soldados que desertaron en masa en el frente oriental, y Maria Bochkareva propuso a Kerensky la creación de batallones exclusivamente femeninos. De hecho, salió del Palacio de

27. M. Del Moral, "En los márgenes del poder, en primera línea de las manifestaciones obreras: la representación de la militancia femenina en el Partido Socialista (1906-1927)”, Feminismo/s, 16, 2010, 133-134; "Hacia la "modernidad" política: socialistas y republicanas en Bilbao (1904-1910)", Cuadernos de Historia Contemporánea, 38, 2016, 209-225 y “Acción colectiva femenina republicana: las Damas Rojas de Madrid (1909-1911), una breve experiencia política”, Hispania, 226, 2007, 541-566.

28. F.J. Romero Salvadó, “España no era Rusia”. La revolución española de 1917: Anatomía de un fracaso”, Hispania Nova, 15, 2017, 416-442.

29. J. Moreno Luzón, “España y la Gran Guerra: cuatro episodios”, Revista de Occidente, 399, 2014, 71-86 y Modernizing the nation: Spain during the reign of Alfonso XIII, 1902-1931, Brighton, 2012.

30. P.M. Egea, "La Revolución rusa en la prensa murciana: de la desinformación a la manipulación", Sociología Histórica, 8, 2017, 257-290. 
Invierno de San Petersburgo con la promesa de proporcionarle uniformes, equipos e instructores. Desde entonces llamaría a las mujeres «de almas puras» a coger las armas para salvar la madre Rusia y, aunque su discurso atrajo a 2.000 voluntarias, sólo 500 cumplieron con los requisitos, acusando al resto de coquetear con los instructores masculinos, como sucedería con las milicianas españolas retiradas del frente por Largo Caballero en 1937. Parecían estar expandiendo la participación de las mujeres en el ejército más allá de los roles permitidos por cualquier otra potencia europea y la sufragista británica Emmeline Pankhurst llegó a decir en Petrogrado: «Honro a estas mujeres que están dando ejemplo a su país» ${ }^{31}$.

Nuevamente, «España no era Rusia», ni su ejército era rojo, ni el PSOE equiparable a los bolcheviques, pese a la radicalización dialéctica. Por entonces, los socialistas españoles seguían el reformismo legal y sindical de la II Internacional y abogaban por su propia «revolución de febrero», con el propósito de instalar una república de corte menchevique y la democracia burguesa que traerían los aliados a nivel internacional. Su estrategia se apoyaba en un acceso gradual al poder local, que en nada se parecía al asalto a la Bastilla o el Palacio de Invierno. Sólo bajo la presión de la CNT, mucho más deslumbrada por la radicalidad de los soviets, se atrevería el PSOE a marchar a la huelga general en agosto de 1917 que, aunque sólo obtuvo respaldo en las grandes ciudades, fue duramente reprimida ${ }^{32}$.

Ya en 1918, pleno «Trienio Bolchevique», se celebró en Valencia el Congreso de los Campesinos Levantinos, donde se habló de la emancipación económica de la mujer con el criterio de equiparar sus condiciones de trabajo a las de sus compañeros varones y, un año más tarde, se celebraría el Congreso Nacional de la Comedia en Madrid, tras el cual, el anarcosindicalismo agrupó más de 700.000 personas, cifras únicas en el mundo. Según Buenacasa, el teatro se llenó de trabajadores, grupos de intelectuales y no pocas mujeres ${ }^{33}$.

La vaguedad ideológica del comunismo libertario español tampoco representaba entonces, pese a su fuerza numérica, una verdadera amenaza para el régimen. No creía en la burocracia y, por tanto, no era un partido férreo y organizado para tomar el poder y conquistar el Estado, ya que su fin era destruirlo a través de la «acción directa». De modo que, no sin contradicciones, los congresos de socialistas y anarquistas españoles optaron por adherirse a la recién creada Internacional Comunista en 1919, con la oposición de UGT. Los principales defensores del bolchevismo habían comenzado a editar un año antes el semanario Nuestra Palabra y la Casa del Pueblo de Madrid hizo entonces su primera manifestación pública de admiración a Rusia. Tras un debate interno, decidieron enviar a Moscú a dos de sus hombres fuertes, Fernando de los Ríos y Daniel Anguiano, pero salvo Ramón Merino, recién nombra-

31. J. McDermid y A. Hillyar, Midwives of the Revolution... op. cit., 181.

32. F.J. Romero Salvadó, “España no era Rusia”, op. cit., 439 y 442, y “The organized labour movement in Spain: The long road to its baptism of fire, 1868-1917”, Tesserae, 2:1, 1996, 1-27.

33. M. Buenacasa, El movimiento obrero español... op. cit., y A. Arru, Clase y partido en la Primera Internacional. Madrid, 1974. 
do líder de la escisión comunista de las Juventudes Socialistas, ninguno de los representantes españoles en el II Congreso de la III Internacional volvió satisfecho ${ }^{34}$.

El delegado de la CNT entre julio y agosto de 1920 fue Ángel Pestaña y el informe de su estancia, publicado en 1925, mostraba su decepción con esa dictadura de partido único. Sin embargo, en lo referente a las trabajadoras, la Komintern reclamó más representación de éstas en sus organismos, incorporando las experiencias soviéticas. Lenin insistió en «la conexión inquebrantable entre la posición humana y social de la mujer, y la propiedad privada de los medios de producción». Sostenía que para mudar sus condiciones de opresión en el seno de la familia, los comunistas se debían esforzar por unir el movimiento feminista con la lucha del proletariado, y atribuía la debilidad de la «cuestión femenina» en la Internacional a las ideas machistas que subestimaban la importancia de construir con ellas un movimiento de masas ${ }^{35}$.

De hecho, influenciados por August Bebel y Clara Zetkin, los partidos de izquierda y los sindicatos anarquistas consideraban que las organizaciones feministas deseaban frenar esa marea revolucionaria, atender al sufragio y los problemas de la mujer burguesa, olvidando las reivindicaciones de las trabajadoras. Figuras tan progresistas como Adolfo González Posada o Francos Rodríguez, juzgaron su feminismo de «oportunista y conservador», al silenciar puntos como el divorcio, el aborto, las uniones libres, el control de la natalidad y la supresión de la ilegitimidad, tan importantes para las obreras con hijos, como se manifestó en Rusia.

Podemos concluir con la tesis de Juan Avilés, según la cual, los anarcosindicalistas y socialistas españoles constituirían una «tercera vía» después de 1920, que se interponía entre gran parte de la clase obrera mundial, que veía en Rusia el modelo para convertir la utopía en realidad, y la elite política y la opinión pública contrarrevolucionaria, que consideraba nefasta la experiencia colectivista. Esta vía creía que el comunismo no podía establecerse con los métodos dictatoriales de la URSS, que impuso 21 condiciones para prohibir a los moderados su entrada en la Komintern. Fueron los delegados españoles en Moscú quienes mostraron que las culturas políticas de su movimiento obrero estaban muy distantes de la bolchevique, que sólo convenció a la escasa militancia inicial del PCE. Los socialistas optaron así por preservar su autonomía y escindirse en junio de 1921, cuando encontraron en la Internacional de Viena la alternativa a la socialdemocracia junto a otras facciones de Alemania, Francia e Italia.

Sin que las noticias de la persecución de la Cheka a los centros anarquistas de Moscú hubieran llegado a España, Andreu Nin y Joaquín Maurín acudieron como representantes de la CNT a la Internacional Sindical Roja celebrada ese verano bajo la dirección del PCUS. Esto provocó otra escisión entre los anarquistas españoles, que, inspirados por las críticas de Emma Goldman, abogaron por su salida de la ISR en 1922, a excepción de Nin y Maurín. El primero se exilió como funcionario en Rusia, y el segundo publicaría en Lucha Social acerca de la moderna sociedad soviética, la emancipación femenina y la libertad sexual ${ }^{36}$.

34. J. Avilés Farré, "El impacto de la revolución rusa en las organizaciones obreras españolas (1917-1923)", Espacio, Tiempo y Forma. Historia Contemporánea, 13, 2000, 17-31.

35. A. Pestaña, Informe de mi estancia en la U.R.S.S., Madrid, 1968.

36. J. Avilés, La fe que vino de Rusia: la revolución bolchevique y los españoles, 1917-1931, Madrid, 1999. 
No obstante, podemos fijar la fecha de 1921-1922 como un fin de ciclo, el final del deslumbramiento de la Rusia revolucionaria en la política española, hasta su resurgimiento con la radicalización de la II República, de la mano de Largo Caballero. De tal modo que el Boletín de Información Antikomintern de 1938, describiría hasta tres ciclos de viajeros españoles a Rusia: los impulsados por la curiosidad ante los hechos, como De los Ríos y Pestaña (19211925); los motivados por una reacción sorda contra Primo de Rivera, con Álvarez del Vayo o Hidalgo (1926-1931), y los de la tercera fase, que se movían entre el deseo de información, los anhelos de imitación y el puro diletantismo, como serían los casos de García Sanchíz y Chaves Nogales, Llopis y Alberti, respectivamente (1931-1936) ${ }^{37}$.

\section{Los Amigos de la Unión Soviética}

A pesar de esto que acabamos de decir, la información directa sobre la Gran Guerra y la Revolución Rusa que llegó a España se consiguió a través de intermediarios extranjeros, a excepción de las crónicas de Sofía Casanova para $A B C$, entre 1915 y 1918, que publicaría un año más tarde como Impresiones de una mujer en el frente orienta ${ }^{38}$. El modelo ruso que ésta transmitía, así como la experiencia que Fernando de los Ríos publicada con éxito en 1921, las de Del Vayo y Ricardo Baeza en 1922, sobre Ucrania, o el célebre H.G. Wells en 1920, más favorable al bolchevismo, hicieron que los conservadores y liberales españoles se convencieran de la necesidad de aplicar algunas reformas, para frenar la ola revolucionaria ${ }^{39}$.

Por su parte, numerosos intelectuales aliadófilos de la talla de Luis de Zulueta, militantes del Partido Republicano Catalán como Marcelino Domingo y Gabriel Alomar, o Luis Araquistain y Julián Zugazagoitia, miembros del sector crítico del PSOE, conservaron las esperanzas en el país de los soviets. Pese a las enormes contradicciones que esto les suponía, perdonaron el Pacto de Brest-Litovsk, así como que disolviera la Asamblea y el sufragio en 1918, e incluso se mostraron escépticos ante las noticias sobre las consecuencias sangrientas de su toma del poder, que tildaron de calumnias, aunque poco después se sumaban a la decepción por las condiciones draconianas de ingreso en la Komintern. El ugetista Julián Besteiro también se opuso a la condena de los bolcheviques por la Internacional Socialista de Berna en 1919, y El Socialista reprodujo continuos editoriales sobre la Rusia mártir. Esta postura se mantuvo hasta la citada escisión del PSOE tras su tercer congreso extraordinario, en 1921, cuando se decidió que no se plegarían a las exigencias de Moscú. Entre quienes se

37. "Viajeros españoles a Rusia entre 1921 y 1936”, Boletín de Información Antikomintern, 10, 1/04/1938, $13-15$.

38. P. Ochoa, "Sofía Casanova entre Polonia, Rusia y España. Género, espacio público y nacionalismo en la I Guerra Mundial (1914-1918)”, Cuadernos de Historia Contemporánea, 38, 2016, 279-302; A. Bernárdez, "Sofía Casanova en la I Guerra Mundial: una reportera en busca de la paz de la guerra" y O. Osorio, "Los orígenes del trabajo periodístico de Sofía Casanova al inicio de la I Guerra Mundial”, Historia y Comunicación Social, 18, 2013, 207-221 y 19, 2014, 47-60.

39. J. Avilés, "El impacto de la revolución rusa en España, 1917-1922”, en J. Tusell, J. Avilés, R. Pardo, La política exterior de España en el siglo XX, Madrid, 2000, 117-134. 
opusieron a esta salida se encontraría Virginia González, miembro del comité de huelga en 1917, de la Ejecutiva y del Comité Nacional del PSOE y la UGT, y que salió del Grupo Femenino Socialista de Madrid «dando vivas a la Internacional y al Partido Comunista» ${ }^{40}$

La creación de la Asociación de Amigos de la Unión Soviética en España (AUS) no se fraguaría hasta 1933, pero hemos de remontar su origen precisamente a esos sectores juveniles y revolucionarios del PSOE que acudieron a la celebración de la III Internacional en Moscú, y que formaron en 1921, con apenas un millar de militantes, el PCE.

No obstante, con la represión del movimiento obrero durante la Dictadura de Primo de Rivera, las españolas sufrieron la actitud ambigua del régimen, con aspectos como el derecho al voto de solteras y viudas, o la implantación entre 1923-1929 del seguro de maternidad. Socialistas y anarquistas no participaron en la Asamblea Nacional ni en los ayuntamientos, aunque en figuras como Federica Montseny aflorara un «feminismo humanista»: «Yo leí y me interesé por todo. Pero lo que contribuyó a formar mi conciencia de militante fue el espectáculo de las terribles luchas sociales en la Cataluña de los años veinte» ${ }^{41}$.

Ya en 1925 la valenciana María Cambrils publicaría el Feminismo Socialista, obra fundamental prologada por Clara Campoamor y dedicada a su «venerable maestro», Pablo Iglesias. Inspirada por Bebel, Cambrils escribió: «las mujeres obreras no podemos olvidar que la única fuerza política de solvencia moral francamente defensora del feminismo es el socialismo» y definió su obra como «alegato contra la injusticia, la opresión, el matrimonio indisoluble y las violencias con las afecciones del corazón $»^{42}$.

Con la proclamación de la II República y la secularización del gobierno social-azañista llegaron las grandes medidas para la equiparación de los sexos en el campo del sufragio universal, la legislación laboral o el derecho conyugal y el divorcio. Tras el célebre debate en las Cortes Constituyentes entre Victoria Kent y Clara Campoamor, llegaría el turno de otras diputadas socialistas como María Lejárraga o Regina García, que en 1933 constituyeron la sección española del Comité Internacional de Mujeres contra la Guerra y el Fascismo, cuya sede se encontraba en París, y que estuvo presidida por Dolores Ibárruri.

Poco antes, y con motivo de la celebración del décimo aniversario de la URSS, en noviembre de 1932, se habían creado las Asociaciones de Amistad con la Unión Soviética, dentro de un Congreso Mundial cuya finalidad era desmontar las mentiras urdidas por el «cordón sanitario» de los países capitalistas. El principal instrumento de propaganda empleado para ello sería la revista Rusia de Hoy, que comenzó a editarse en junio de 1933 con una tirada de 10.000 ejemplares y que pronto aumentó a 50.000. El último número antes de su suspensión por el gobierno radical-cedista, tras la Revolución de Octubre, fue el de julio de 1934 y salió con la imagen en portada del deporte femenino en la URSS.

40. M. Del Moral, "El Grupo Femenino Socialista de Madrid (1906-1914): pioneras de la acción colectiva femenina”, Cuadernos de Historia Contemporánea, 27, 2005, 255.

41. S. Tavera, "Federica Montseny y el feminismo: unos escritos de juventud", Arenal, Año 1/2, 1994, 307-329.

42. En M. Nash, Mujer, familia y trabajo en España (1875-1936), Barcelona, 1983, 70. 
La Komintern contó con la Sección de Mujeres Comunistas y, desde el estallido de la guerra en 1936, activó todos sus recursos para oponerse al Comité de No Intervención a través de otro Comité Internacional de Ayuda a España, dirigido desde París por Ceretti, con el objetivo de prestar ayuda, sobre todo, a las mujeres y niños de la República. En ese sentido, la Asociación de Escritores Soviéticos organizó una velada musical y literaria en diciembre, para recaudar fondos bajo el lema «Estamos con vosotros», mientras los estudiantes recordaban cómo la Ciudad Universitaria de Madrid se había convertido en campo de batalla, a través del discurso del embajador Marcelino Pascua en el Instituto Energético Molotov de Moscú ${ }^{43}$.

Miguel Vázquez Liñán ha analizado la organización de canales y mensajes a través de los cuales el Kremlin «vendió» su modelo de Estado a la República española durante la Guerra Civil. Entre esos medios desplegó la Comisaría de Agitación y Propaganda de las Brigadas Internacionales, donde encontramos a otra mujer destacada: Teresa Noce o «Estela», la mujer del comisario general, Luigi Longo ${ }^{44}$.

Por su parte, Laura Branciforte ha analizado el papel de las mujeres en el Socorro Rojo entre 1923 y 1939. Una organización independiente de la AUS, pero vinculada también a la III Internacional Comunista. Ella comprobó cómo, al igual que Clara Zetkin o Elena Stasova ocuparon los principales cargos directivos, en España la responsabilidad femenina y la afiliación masiva se produjeron tras la Revolución de Asturias. Stasova dirigía además el departamento secreto de la Komintern que proporcionaría los carnés de identidad falsos para que viajasen los funcionarios del SRI, como Carlos Vidali y Tina Modotti, a quienes les encargó la misión de distribuir las ayudas soviéticas entre las víctimas de la represión de 1934. De hecho, las organizadoras del Comité de Mujeres contra la Guerra y el Fascismo en Gijón, Oliva López y Pilar Lada, dirigentes también del PCE local, fueron obligadas a huir, exiliándose en la URSS hasta las elecciones del Frente Popular en febrero de $1936^{45}$.

Durante la Guerra Civil española, Modotti abandonaría su trabajo como fotógrafa en Moscú, siendo enviada a España para dedicarse enteramente al SRI. Tras recorrer todos los frentes junto a su inseparable Matilde Landa, dirigiría la oficina en Barcelona desde octubre de 1937, donde también se encontraría con Margarita Nelken. Ésta trabó amistad con Stasova durante su exilio en Rusia en 1935, empezando a interesarse por la organización y a desvincularse del PSOE, para acercarse cada vez más al Partido Comunista y a la AUS:

En el Manifiesto de los Amigos de la Unión Soviética, ya se dice que, en este país, la vida es simplemente, la expresión del progreso de la humanidad. Para la mujer, es sencillamente la URSS, el país de su dignificación, así como es, para los trabajadores, el único país donde se hallan

43. Komsomol, Órgano del C.P. del Socorro Rojo Internacional de Almería, Año 1/1, 01/05/1937, 7.

44. M. Vázquez Liñán, Propaganda y política de la Unión Soviética en la Guerra Civil Española (19361939), Tesis doctoral, Universidad Complutense de Madrid, 1999, 109, 132, 159 y 275.

45. L. Branciforte, El Socorro Rojo Internacional (1923-1939). Relatos de la solidaridad antifascista, Madrid, 2011, 214-220 y 242. 
emancipados por completo [...] no puede haber tampoco una mujer que no piense, como un supremo anhelo, en las condiciones de vida de las mujeres soviéticas ${ }^{46}$.

Los aspectos más destacados de la constitución soviética para Nelken eran las libertades para conseguir la plena emancipación de la mujer, gracias a la colaboración del Estado en la crianza. Otro aspecto aplaudido por Esther Cornur fue la sanidad pública y algunas medidas inéditas como los profilacterios, creados en 1923 para la reeducación de las prostitutas, como los «liberatorios de prostitución» anunciados por Federica Montseny y la doctora Amparo Poch y Gascón en 1937. Según Solomín, gracias a éstos el número de prostitutas se había reducido en Moscú y Petrogrado de las 150.000 anteriores a 1919, a las 3.000 moscovitas de 1928 y 400 de 1931. Por otra parte, existiría una «consulta para las mujeres» con información sobre sexualidad, que garantizaría abortos con atención profesional y bajas laborales de 10 días, desde la Ley despenalizadora de 13 de noviembre de 1920. En 1926 se calculaba entre el $12-18 \%$ el número de estas intervenciones en la URSS, dando gratuidad y prioridad a las obreras solas sobre las familias numerosas, algo que era fruto del régimen capitalista y que diferenciaba la ley soviética del resto del mundo ${ }^{47}$.

Las embarazadas, por su parte, no podían ser expulsadas de sus empleos, sino que limitaban sus tareas y disponían de suelto anticipado y cuidados, además de una licencia de 56 días para las obreras y de 42 para las intelectuales, antes y después de dar a luz. Ya en 1935 300.000 rusas parieron sin dolor «porque en la URSS está la ciencia al servicio del hombre, al servicio de la madre». Asimismo, su salud y la de los recién nacidos se garantizaría mediante campañas anti-tuberculosis y de alimentación como la «Gota de Leche», implantada en 1910; espacios de lactancia en las fábricas y consultorios contra la mortalidad infantil, tanto en la ciudad como en el campo. De hecho, en los bosques de pinos de Sokolniki, cerca de Moscú, se abrió una casa de reposo donde podían acudir con sus hijos menores de cinco años ${ }^{48}$.

Como ha indicado Magdalena Garrido, la AUS contó con una gran maquinaria publicitaria en toda Europa, cuya misión era ensalzar los logros del único país en que había triunfado la revolución socialista, tras los fracasados intentos de los espartaquistas alemanes, la Viena roja o la Hungría de Béla Kun. Entre los logros que se querían destacar, ya en pleno régimen estalinista, siempre se contaron el trabajo campesino, la cultura de la construcción, el modelo del Ejército Rojo para el Popular republicano, o de la Federación rusa frente a los nacionalismos periféricos, así como la imagen femenina asociada a la lucha y la maternidad ${ }^{49}$.

Los socialistas, comunistas y sindicalistas Amigos de la Unión Soviética que fueron delegados para asistir al XVIII Aniversario de la Revolución en 1935 declararon a su regreso que:

46. M. Nelken, La mujer en la U.R.S.S. y en la Constitución Soviética: conferencia pronunciada en Valencia por Margarita Nelken, el día 4 de Junio de 1937, Valencia, Amigos de la Unión Soviética, 1938, 27-28.

47. Solomin, La emancipación de la mujer en la U.R.S.S., Madrid, 1938, 14-16, 21-33 y 37-46.

48. "Madres felices y buenas ciudadanas", Rusia de Hoy, 2, marzo-abril 1936 y "Niños soviéticos. Una infancia dichosa", Rusia de Hoy, 2, agosto-septiembre 1938.

49. M. Garrido Caballero, Las Relaciones entre España y la Unión Soviética a través de las Asociaciones de Amistad en el siglo XX, Murcia, 2006 [Tesis on line], Cap.5 [sin numerar]. 
En la URSS está plenamente realizada la emancipación de la mujer y la equiparación de ésta al hombre, no sólo de un modo formal, sino efectivo, en el terreno de la producción, de la cultura, del deporte, etc. La superación de los viejos prejuicios ha llevado a una admirable convivencia entre hombres y mujeres dentro de un ambiente de gran elevación moral ${ }^{50}$.

Dos años más tarde, el 12 de diciembre de 1937, la siguiente delegación fue recibida en el Teatro Principal de Valencia en olor de multitudes. La tabaquera madrileña Encarnación Sierra declaró allí: «cada fibra de mi ser está empapada de lo que he visto» ${ }^{51}$. La organización nacional del XX Aniversario en la ciudad del Turia, contaría también ese año con anarquistas de Mujeres Libres o la Federación de Mujeres Antifascistas, organización interclasista y que pretendía agrupar a organizaciones de todo el Frente Popular, pese al liderazgo comunista ${ }^{52}$.

El Comité Nacional de la AUS estaría liderado por Ramón del Valle Inclán y, no sin dificultades, como el asalto de tres fascistas a las oficinas de Madrid, a primeros de mayo de 1933 contaría con dos organizaciones regionales, 27 comités de distrito y 55 grupos locales, que significaban más de 2.000 miembros. Ya en marzo de 1936 las secciones provinciales llegaban a 36, y en 1938 el Boletín Antikomintern de Berlín hablaba de 70.000 afiliados en todo el mundo, considerados como «bases de apoyo y escondites del espionaje soviético» ${ }^{53}$.

Entre los fundadores de la AUS aparecerían mujeres como la diputada socialista María Lejárraga o María Martínez Sierra, como firmaba ella misma; Carmen Monné «de Baroja»; Carolina Carabias, viuda del capitán García Hernández, y María Rodríguez, la de Fermín Galán; Pilar Coello y la escritora Concha Espina ${ }^{54}$. Sabemos que, al igual que Aldous Huxley, André Malraux o Elisabeth de Grammont, María Pérez Enciso también firmó el Manifiesto suscrito por personalidades de la vida pública, bajo su pseudónimo de periodista: Rosario del Olmo. En 1937 ella formaba parte de la comisión ejecutiva del Institut d'Adaptació Profesional de la Dona y la Unió de Dones de Cataluña, pero con la caída de Barcelona en enero de 1939, tuvo que salir de España como delegada del Comité de Evacuación en Bélgica, al cargo de 5.000 niños. En mayo de 1940 cruzaría el Atlántico y en México D.F. se hizo colaboradora de la revista Mujeres Antifascistas Españolas, que la UME publicaba en París. Antes de llegar allí, pasó con su hija por La Habana pre-revolucionaria de Batista, donde vivió en la pensión de Eduardo Ortega y Gasset y su esposa, miembros asimismo de la AUS $^{55}$.

50. M. Garrido Caballero, Las Relaciones entre España y la Unión Soviética... (cap. 5, s/p).

51. "Fue triunfal la recepción a su regreso de la URSS", Hechos de la URSS (ed. Chile), IV/1, enero de $1937,13$.

52. Véase: M. Nash, Rojas. Las mujeres republicanas en la guerra civil, Madrid, 1999.

53. "Los Amigos de la Unión Soviética en España”, Hechos de la Unión Soviética, 8, julio 1933, 10-11 y "Agresión fascista contra la oficina de la AUS en España", 9-10, agosto-septiembre de 1933, 11; "Del movimiento de los AUS", Rusia de Hoy, 2, marzo-abril de 1936 y Boletín de Información Antikomintern, 7-8, 01/03/1938, 9 .

54. A. San Román Sevillano, Los Amigos de la Unión Soviética (AUS): propaganda politica en España (1933-1938), Salamanca, 1994.

55. S. Rodríguez, "Todo sobre mi madre. Un relato generacional de la vida y exilios de Carmen Tortosa", en Mujeres Iberoamericanas y Derechos Humanos. Experiencias feministas, acción política y exilios. Sevilla, 
No sabemos si ambos colaboraron en la segunda época de la revista Rusia de Hoy, cuando tras la victoria del Frente Popular, los editoriales pedían al ministro de Estado, Augusto Barcia, que reconociera diplomáticamente a la URSS, y se dedicaban números casi íntegros a las mujeres. Carmen Dorronsoro escribía una crónica desde Moscú, comparando las «modistillas» españolas con las estajanovistas del textil ruso. Deslumbrada por las instalaciones formativas, culturales, sanitarias y el kindergarten de la fábrica, hacía hincapié, sobre todo, en la productividad alcanzada gracias a las buenas condiciones laborales:

Ved ahí, obreras de la aguja de España, cómo mientras muchas de vosotras enfermáis debido a las malas condiciones de trabajo y escasa alimentación [...] no teniendo inconveniente alguno de poneros en la calle cuando les parece, aquí en la Unión Soviética los obreros de la costura trabajan con entusiasmo porque saben que es para ellos $^{56}$.

Otro de los objetivos del artículo era alabar el buen gusto en el diseño y la feminidad de estas revolucionarias, frente a la «creencia de que la mujer soviética era una especie de marimacho, vestida de una manera estrafalaria y destacándose siempre el descuido»,

Si se la ve frecuentemente con el mono de mecánico en el andamio o conduciendo un camión, o tirándose con un paracaídas, esto no quiere decir que cuando llega la hora de vestirse y arreglarse, no le guste hacerlo y lo haga cada día mejor, pues es en la URSS precisamente donde las mujeres «todas» pueden permitirse el lujo de pensar en sus trapos, ya que las preocupaciones de otro orden están en su mayoría resueltas.

Esta contrapropaganda a la prensa Antikomintern preocupaba también a Sonia Kienia, técnico del metro de Moscú que, en una «Carta a las mujeres de los países capitalistas», explicaba cómo se forjó a sí misma desde un pequeño pueblo de la frontera polaca y llegó a desafiar a sus superiores, siendo la primera obrera en trabajar en una cámara de aire comprimido. Gracias a la peligrosidad de esta tarea, prohibida por la legislación laboral, cobraría un sueldo de 673 rublos, con los que comprar bonitos vestidos. Y es que incluso el Komsomol, Comité Central de las Juventudes Comunistas, llegó a organizar una reunión en diciembre de 1935 para discutir cómo debían vestir las muchachas. No era imprescindible, en cambio, que para casarse lo hicieran de blanco, y el mismo número de la revista ilustraba una boda civil «sin ritos aparatosos ni complicados trámites», en la que los contrayentes sólo debían presentarse en el Registro con sus certificados de nacimiento y domicilio, contestar a unas preguntas sobre su salud y situación familiar, y pagar tres rublos al funcionario.

2016, 348-383; A. Rodrigo, "María Enciso: una pincelada de cal en la ciudad provinciana", Meridiana, 4, 1997 y Mujer y exilio, 1939. Madrid, 1999; F. Montiel Rayo, "Enciso, María", Diccionario bio-bibliográfico de los escritores, editoriales y revistas del exilio republicano de 1939. Vol. 2. Sevilla, 2016, 244-245.

56. "Cartas de Moscú. Las modistas soviéticas" y "Una stajanovista del ramo textil”, Rusia de Hoy, 2, 1936. 
¡Socialización de las mujeres! ¡Disolución de la familia! ¡El niño arrebatado a su madre! Estupideces, simplezas o mentiras que han propalado los enemigos de la U.S. en sus calumniosas campañas. La «unión libre» existe en la URSS sin que nadie resulte perjudicado [...] En la U.S. no puede prosperar el vicio; nada pues de bigamia ni abandono de niños ${ }^{57}$.

Desde octubre-noviembre de 1936 las solicitudes de material de propaganda por parte de la AUS a la Comisaría de Asuntos Exteriores de la URSS fueron constantes. Entre ellos reclamaban artículos, discos, folletos, carteles y fotografías recientes sobre las grandes infraestructuras soviéticas, los koljoses y sovjoses, así como el papel de las mujeres en la guerra, y su situación y la de la infancia en el nuevo Estado. Si entre las películas y documentales producidos en estudios soviéticos, podríamos destacar En ayuda de los niños y mujeres de la heroica España, de 1936, no fue menor la influencia rusa en las cintas de los cineastas españoles: Mujeres trabajadoras, Mujeres Antifascistas o La mujer en la guerra ${ }^{58}$.

Desde su creación, las Ediciones AUS distribuyeron también sin ánimo de lucro cientos de títulos como: La situación de la mujer en la U.S de Cora Grahan, y La mujer y los jóvenes en la U.S., de Mira Page, ambos de 1937; La lucha contra la prostitución en la URSS, traducción de Gráficas Turia en 1938 a la edición francesa de Moscú en 1936, por Vol’f Moiseevich Bronner; los fragmentos de discursos y artículos de Lenin sobre La cuestión femenina (19181922), con prólogo de Nadezhda Krupskaia y lanzados por Ediciones Europa-América, al igual que La nueva mujer de la Unión Soviética (1937) y la ya citada obra de Solomin, La emancipación de la mujer en la U.R.S.S. (1938).

Entre mayo y junio de 1937, coincidiendo con la reconstitución de la Asociación tras su II Congreso Nacional, se organizaron dos actos: el ciclo de conferencias en que participó Margarita Nelken y una exposición fotográfica itinerante por Valencia, Madrid, Jaén, Murcia y Albacete, dedicada a los Veinte años de construcción socialista y dividida en 13 secciones, como «La protección de la mujer y el niño como característica de la vida soviética». Meses más tarde, coincidiendo con el XX Aniversario de la Revolución, otra muestra titulada Veinte años por la paz y la amistad de los pueblos contenía de nuevo un stand sobre «La mujer y el niño», uno de los lemas orgánicos sobre los logros sociales de la Constitución de $1936^{59}$.

El $A B C$ de Madrid tampoco dejó de publicar mensajes de agradecimiento a las obreras de las repúblicas más orientales de la URSS, como Kirguizia, por los continuos envíos de ayuda humanitaria. En ellos se hablaba de las «mujeres de Moscú, obreras, empleadas, ingenieros, médicos, profesoras, actrices, estudiantes, técnicos y madres de familia» que, pese a haber

57. "Un casamiento en la URSS” y "Carta de una obrera del metro de Moscú a las mujeres de los países capitalistas", Rusia de Hoy, 2, marzo-abril 1936.

58. Traducido de: Na pómosch détiam i zhénschinam gueroicheskoi Ispanii. Véase: M. Crusells, La Guerra Civil española: cine y propaganda, Barcelona, 2000.

59. M. Vázquez Liñán, "Los mensajes de la propaganda soviética durante la Guerra Civil española” y "La propaganda soviética en la guerra civil española: la asociación de amigos de la Unión Soviética”, Eúphoros, 6, 2003, 67-76 y 3, 2001, 181-188. También: J.M. Faraldo, “Conmemorar 1917 en 1937: Moscú-MadridMoscú", Revista de Occidente, 437, 2017, 19-40. 
sufrido el yugo zarista, enviaban ánimos a las españolas, con casi un 50\% de analfabetas, para alcanzar una patria tan «poderosa, floreciente y próspera» como la suya ${ }^{60}$.

Para poder emplearse fuera del hogar, las soviéticas disponían de las casas-cuna del Estado, como la prestigiosa Casa de Maternidad Clara Zetkin, atendidas por pedagogas y descritas como hoteles de lujo, junto a los campos de pioneros que se exportaron a España. Como insistía la viuda Nadezhda Krupskaia, con disponibilidad de tiempo y sus derechos civiles garantizados, las mujeres podían elegir entre desarrollar una carrera política o profesional con una educación pública de calidad, cultivarse en sus prestigiosos conservatorios de música, trabajar como stajanovistas o quedarse en casa para cuidar de su familia, sin que les hiciera falta maquillajes ni afeites, dada su buena salud y aspecto vigoroso... ${ }^{61}$.

A golpe de estadísticas sobre el éxito de los Planes Quinquenales, de semblanzas de jóvenes soviéticas «realizadas» y de panegíricos como los de los visitantes españoles, la propaganda estalinista mostraba sus grandes inversiones y avances por la plena alfabetización, mecanización, contratación, seguros sociales o la «revolución cultural» que supuso el aumento exponencial de la investigación científica, los clubs, cines, teatros de fábrica o bibliotecas populares. Según Hechos, la abolición del paro y de la explotación de popes y kulaks representaban una mejora que la clase obrera de los países democráticos no podría soñar.

El aumento del nivel de vida material se plasmaría en la duplicación del gasto público para la protección de la salud, la disminución del precio de los productos básicos en un $40 \%$ y el aumento de los salarios en más del 60\%, al final del II Plan. De modo que Luis Codina, un empleado gráfico de la Juventud Federal de Madrid que visitó la URSS en 1935 afirmaba que, si el salario medio era de 250 a 400 rublos, los obreros cualificados llegaban a «ganar más que cualquier miembro del gobierno soviético». Ese año, el auge de la actividad comercial por el incremento del poder adquisitivo hizo que las revistas mostraran imágenes de tiendas y colmados donde «la obrera soviética se elegantiza por momentos» al escoger calzado, un sector que creció un 31\%, así como la producción de medias o tejidos de seda, con un $16 \%{ }^{62}$.

Las obreras de Leningrado aumentaron en 25.000 entre 1929 y 1931, hasta constituir la mitad de su proletariado. Destacaban las industrias básicas de la metalurgia y el sector eléctrico, donde pasaron del 14 al 25\%; en la madera, del 17 al 33\%, y en el textil, del 71 al $76 \%$ entre 1923 y 1932. Se decía que gran número de las nuevas empleadas en la industria eran «antiguas mujeres de su casa», aunque la mitad de los inmigrantes a la ciudad eran campesinos/as de los sovjoses y koljoses, que en ningún tramo de edad superaban el $9 \%$ de analfabetismo. Aunque entonces la industria suponía el 70,4\% de la economía nacional, entre

60. Soviet Russia and Spain: the full story of the Soviet Union's role in the fight for democracy in Spain, London, 1938 y La Unión Soviética defiende los derechos de la República Española: dos años de leal amistad, Valencia, 1938. Véase: M. Vázquez Liñán, Propaganda y política... op.cit, 144-152, 182, 194, 210-265, 302, 309 y N. De Gabriel, “Alfabetización y escolarización en España (1887-1950)”, Revista de Educación, 314, 1997, 217-243.

61. N. Krupskaia, "La mujer libre y feliz del país del socialismo", La Internacional Comunista, VI, 2-3, $1938,53$.

62. “Impresiones de los delegados” y “Tiendas soviéticas”, Hechos, 2, noviembre 1935. 
las coljosianas [sic] habría 6.000 presidentas, 28.000 jefes de brigada, 100.000 directoras de grupos, 9.000 dirigentes de explotaciones comerciales y 7.000 conductoras de tractores... «Por esto debemos nosotros señalar como un signo indiscutible de nuestro progreso social, la actividad social de las mujeres trabajadoras, así como su elevación a los puestos dirigentes» ${ }^{63}$.

De este modo, la población total de la URSS había pasado de 160 a 168 millones entre 1930 y 1933, y su riqueza nacional aumentado de 35.000 a 50.000 millones de rublos. Moscú y Leningrado se habían consolidado entre las primeras siete ciudades del mundo, junto a Nueva York, Londres, Berlín, Chicago y París. La comparación con las capitalistas occidentales que sólo se dedicaban a reproducir el modelo liberal burgués de «ángel del hogar» resultaba odiosa, y es que si la proporción de obreros/as en las escuelas superiores soviéticas era del 51'4\%, en Alemania no pasaría del 3,2\% entre 1923-1933, cuando Hitler llegó al poder. Como alertaba Clara Zetkin: «el fascismo nos quita los derechos conquistados en una lucha cruel y nos niega la independencia y el trabajo. Acordaos de que el Tercer Imperio os quiere convertir en sirvientas del marido y en máquinas de parir» ${ }^{64}$.

\section{Los Enemigos de la Unión Soviética}

Si la opinión pública nacional parecía favorable al principio a la caída del Zar, e incluso la monárquica Casanova se mostró partidaria de la toma del poder por el pueblo ruso, al final de la Gran Guerra la prensa española prestaría más atención a «la locura roja». La traducción de libros franceses, británicos y alemanes Antikomintern como Das Rotbuch über Spanien y Der Weltbolschewismus (El libro rojo de los españoles, 1937 y El bolchevismo mundial, 1938), también contribuyeron a difundir la imagen de un régimen tiránico.

Las críticas hacia la situación social en Rusia surgieron ya en la prensa contemporánea a la Revolución durante la Restauración española. Como han indicado Wendy Goldman o Pedro Egea, el amor libre de Alexandra Kollontai, así como la supresión del matrimonio, fueron contemplados por los detractores de la revolución como vía libre para la corrupción de menores. Así, el periódico El Tiempo de Murcia, llegó a hablar de «barbarie bolchevikista» en el distrito de Wladimir, donde «jóvenes esposas y doncellas habían sido flageladas por negarse a reconocer la validez de los llamados bonos de amor ${ }^{65}$. La destrucción de la moral burguesa del Contrato Social, la familia católica y la infancia fue norma común en la propaganda Antikomintern, que no dudó en apelar al sensacionalismo y al converso Gorki para justificarlo. Sus detractores criticaban así en 1919 el comercio con turcas, armenias y kurdas

63. "La vida de los trabajadores", Hechos, 12, noviembre 1933, 7-8; "El desarrollo de las ciudades socialistas", 13, diciembre 1933, 7 y, sobre todo, "El ascenso económico de la Unión Soviética” y "Las líneas generales del II Plan Quinquenal, 1933-1937”, 14, febrero 1934, 3-13.

64. M. Vázquez Liñán, Propaganda y política... op.cit, 339 y 376.

65. P.M. Egea, “La Revolución rusa en la prensa murciana...”, op.cit, 274 y W.Z. Goldman, “ «Del pasado hay que hacer añicos»: la liberación de las mujeres y la Revolución rusa”, en J. Andrade y F. Hernández (Eds.), 1917. La Revolución rusa cien años después, Madrid, 2017, 133-152. 
en el Cáucaso, tanto como la brutalidad de la Guardia Roja con la propia Emperatriz y las Grandes Duquesas, que otrora retratara Tolstoi en la tan leída Anna Karenina.

Incluso las estrictas normas cívicas del anarcosindicalismo español en lo referente a la prostitución y otras restricciones moralistas, hicieron que algunos ateneos libertarios y casas del pueblo prohibieran el café, el alcohol y los bailes por considerarlos perniciosos, lo cual conjugaba mal con esa apología del amor libre ${ }^{66}$.

Doña Emilia Pardo Bazán, coruñesa como Sofía Casanova y bien informada por la prensa francesa, escribió también numerosos artículos sobre la marcha de la Gran Guerra en La Ilustración Artística de Barcelona, La Nación de Buenos Aires y el Diario de la Marina en La Habana. Frente a la información de primera hora de la reportera, la Condesa mostraba una sorpresa rayana por los acontecimientos, ya que «de Rusia se sabe aquí poco o nada». Recordaba también en el diario bonaerense que muchos años atrás ella había hablado en el Ateneo de «La revolución y la novela en Rusia», a través del testimonio de nihilistas refugiados y publicistas rusos que había conocido en París, quienes consideraban la Constitución del Zar como «papel mojado». La relación entre aquellas ideas y la revolución presente no le causaba buena impresión y dudaba de la oportunidad del levantamiento popular, a pesar de que le parecía increíble que las damas de la corte de Rusia hubiesen encumbrado a Rasputín, y veía peligrosísimo el «cambio de cabeza» de la familia Romanov.

Ya en 1918 mostró su total desacuerdo con la revolución bolchevique y en la «Crónica de España» aparecida en febrero de 1919 en La Nación, abordaba el contagio de esa «locura colectiva» que podría llegar a implantar en nuestro país una República laica. Ella no se oponía a una república de orden, sino aquella cuyo modelo fuera el soviético, pero la consideraba inviable dada la idiosincrasia de los católicos españoles, que ambicionaban paz y orden, pues «antes de que los apóstoles rusos llegasen a Barcelona, se había hecho bolshevikismo o bolshevismo, como ustedes prefieran, en España, saqueando, a placer, en no pocas provincias». Finalmente, reconocía que las teorías sociológicas marxistas no habían forjado un mundo más justo, libre y feliz en Rusia, sino que calificaba la experiencia como «decisiva y terrible» debido a las desgracias, atrocidades y matanzas que llevaron consigo ${ }^{67}$.

Otros intelectuales como Madariaga o Unamuno consideraban el fenómeno soviético como propio del espíritu asiático, y no veían tanto peligro en el Ejército Rojo como en la propagación de sus ideas entre los anarquistas catalanes y andaluces. Ya al término de la Guerra Civil rusa, con el «tapón» de Polonia y la NEP, otros como Ramiro de Maeztu dieron la revolución por fracasada y la amenaza superada, pese a la seguridad que les reportó la lucha declarada de Primo de Rivera contra el comunismo y el judaísmo internacional ${ }^{68}$.

66. A. Aguado y D. Ramos, La Modernización de España (1917-1939). Cultura y vida cotidiana. Madrid, 2002.

67. R. Martínez, “Emilia Pardo Bazán y Sofía Casanova, cronistas de la Gran Guerra”, La Tribuna, 10, 2015, 51-92 y Sofía Casanova: mito y literatura, Santiago, 1999.

68. J. Avilés, “El impacto de la revolución rusa en España, 1917-1922”, en J. Avilés. "El impacto de la revolución rusa en España...”, op. cit., 117-134. 
Durante la Guerra Civil española, las críticas al modelo de revolucionarias rusas provinieron también de la fuerte división existente en el seno del Frente Popular. La Agrupación de Mujeres Antifascistas, liderada por un PCE gregario de la URSS, se enfrentaría a su antagonista feroz, la Agrupación Femenina del POUM, partido trotskista liderado por Andreu Nin, tras su abandono de la CNT y su estancia en Moscú. De hecho, una de las afiliadas de esta última, Mercedes Abril, afirmaba con motivo de un mitin celebrado en Barcelona, que aquella era el centro de las reaccionarias del país, en el que habían buscado albergue todas las Teresianas, Hijas de María y del Sagrado Corazón... y demás «fauna clerical», tildando a Margarita Nelken de madre abadesa de estas «supuestas antifascistas» que se hubieran convertido rápidamente en falangistas de haberse encontrado en la zona fascista ${ }^{69}$.

De hecho, la Sección Femenina de Falange se apoyaría en textos del propio Trotski que, en el marco de la IV Internacional de 1938, reconocía las conquistas de la mujer en la URSS, aunque dedicó parte de La revolución traicionada a «La familia, la juventud y la cultura»:

Por desgracia, la sociedad fue demasiado pobre y demasiado poco civilizada. Los recursos reales del Estado no correspondían a los planes y a las intenciones del Partido Comunista. La familia no puede ser abolida: es preciso substituirla. La verdadera emancipación de la mujer es imposible en el terreno de la miseria socializada. La experiencia reveló muy rápidamente esta dura verdad, formulada hace cerca de 80 años por $\operatorname{Marx}^{70}$.

Para Trotski y todos los «desencantados» con la dictadura del proletariado, el principal enemigo de los ideales revolucionarios de la Unión Soviética sería el propio Stalin. Así lo sintieron también las mujeres que relataron sus experiencias al término de la Segunda Guerra Mundial. Para entonces no quedaba nada del red love de 1917 y prevalecía un decreto por el que las mujeres doctorandas, cuya misión era escribir tesis para el Estado, no tenían derecho a tener hijos, de modo que quienes recurrían al aborto lo hacían ya en la ilegalidad ${ }^{71}$.

Stalin se cuidó de reforzar su papel en la familia desde finales de los años treinta: «su misión es educar nuestra infancia, nuestra futura generación, nuestro porvenir» ${ }^{72}$. Esta «biopolítica» se concretaría con nuevas prohibiciones al control de la natalidad y fomento de las familias numerosas, como sucedía paralelamente en los regímenes fascistas de Europa ${ }^{73}$.

La edición chilena de la revista Hechos de la URSS publicaba su primer número de 1937 salpicado de imágenes de colegialas con «una amplitud de horizontes satisfechos en sus caritas sonrientes»; dos futuras pilotos en el aeródromo de Erivan; un cuerpo femenino auxiliar del Ejército Rojo y la campeona de natación Maria Sokolva. Sin embargo, en páginas interiores se incurría en tremendas contradicciones a propósito de las nuevas leyes sobre el

69. M. Roig, La mujer en la historia a través de la prensa: Francia, Italia, España. Siglos XVIII-XX. Madrid, 1989.

70. L. Trotski, La revolución traicionada, 1936. (Citado por Stauffer en 1939).

71. C. Simmons y N. Perlina, Escritos de mujeres... op. cit., 156.

72. M. Vázquez Liñán, Propaganda y política... op.cit, 337.

73. M. Foucault, Historia de la sexualidad. Vol. 1. La Voluntad de Saber. Madrid, 1996, 168. 
matrimonio del TSIK (Comité Central Ejecutivo de la URSS). El asunto parece que fue motivo de polémica en una supuesta consulta popular donde opinaron sobre todo las mujeres, haciendo hincapié en los cambios implantados desde 1920 respecto a la legitimidad de los hijos, sin importar el estado civil de los progenitores, así como al aborto. No obstante, el 28 de junio de 1936 la nueva Ley prohibiría los abortos, salvo peligro de vida, e incentivaba, en cambio, a las familias que superaran los seis vástagos, con pensiones de 2.000 rublos durante cinco años o 5.000 por hijo, las que tuvieran más de diez. Con la «intención de fomentar la responsabilidad de los padres», el divorcio también sería restringido, debiendo comparecer ante un oficial para exponer las razones de separación y pagar 50 rublos, si se trataba de la primera vez, 150 la segunda y 300 la tercera... cien veces más de lo que costaba casarse ${ }^{74}$.

Haciéndose eco de esta noticia, el Boletín de Información Antikomintern hablaba en 1938 de la lucha contra la tradición y la familia librada en Rusia, donde no había un menor de 25 años que hubiera pisado la iglesia. Siguiendo al dios del materialismo, la contrapropaganda a esa sencilla unión civil que veíamos en la revista Hechos comentaba:

El matrimonio no es santificado y la vida familiar no se considera respetable. Es cierto que los divorcios son ya más difíciles, pero ello es debido sólo a motivos económicos y no a razones morales. Los divorcios eran tan frecuentes y repetidos que muchas veces los empleados soviéticos no podían comprobar siquiera quienes eran los padres de los niños ${ }^{75}$.

Si las afinidades ideológicas se tradujeron a comienzos de siglo en amistades personales, como la que sostuvieron Lenin y Nadezhda Krúpskaya con Rosa Luxemburgo, o con Trostki y su esposa, Natalia Sedov, la muerte del líder anunció un período de gran inseguridad para su familia y el antiguo buró político, enfrentado a una crisis intestina por el liderazgo ${ }^{76}$. De hecho, la hermana de Lenin, Maria Ulianova, llegó a participar con Stalin en los debates del Partido Comunista de la Unión contra Zinoviev, Kamenev y Krupskaia, su cuñada, aunque se retiró por el empeoramiento de la situación. Ambas formaron parte, finalmente, de la comisión de 36 militantes que condenaría a Bujarin y Ríkov, retenidos en la Lubyanka en 1937. «Las dos mujeres, a las que Stalin había comenzado a agredir y marginar aún en vida del líder, infinitas veces habían visto a Vladimir Ílich hablar y discutir con Bujarin y ahora aceptaban en silencio las mentiras de Mikoyán, elaboradas por Stalin» ${ }^{77}$.

¿En qué se parecían esas sombras a «La mujer libre y feliz del país del socialismo» que escribiera Krupskaia en La Internacional Comunista ese mismo año? El propio Boletín Antikomintern la calificaba como un «ejemplar de museo», después de su designación como Comisaria del Pueblo de Instrucción Pública:

74. J. Smith, "El nuevo matrimonio soviético y las leyes de la familia”, Hechos de la URSS, IV/1, 1937, 7 y 15.

75. CDMH, Boletín de Información Antikomintern, 5, 15/01/1938, 17.

76. O. Novlkova, "Rusia, 1917. La revolución del pensamiento, la cultura y las emociones”, op. cit., 25

77. L. Padura, El hombre que amaba a los perros. Barcelona, 2011, 258, 516 y 521. 
Después de haber exterminado [...] a todos los supervivientes de la época de Lenin, Stalin se queda ahora con su viuda para utilizarla como elemento de propaganda y al mismo tiempo para que Rusia conserve en ella el testimonio de una época de especies ya totalmente extinguidas ${ }^{78}$.

Trotski vivió lo suficiente para reconocer la traición, conocer la muerte de sus hijas y la condena a un campo de trabajo de su hermana, Olga Bronstein, la esposa de Kámenev. Él denostaba la AUS como comparsa estalinista y siempre denunció que Stalin utilizó la Guerra de España como moneda de cambio en sus tratos con Hitler. Orlov, el NKVD y «los viejos e incondicionales amigos de la URSS», consiguieron que mucha gente siguiera creyendo en la ayuda magnánima que les prestaban ${ }^{79}$.

Si en estos términos se expresaban los viejos bolcheviques, era lógico que la propaganda contrarrevolucionaria de las falangistas de Sección Femenina se encargara de mostrar la deplorable situación que vivía la URSS en 1939. La responsable de propaganda, Clarita Stauffer, escribió entonces sobre «La mujer y el marxismo», denunciando la facilidad de los divorcios, pese a esas nuevas leyes de Stalin, y culpando a los comunistas judíos del alto costo social:

Durante 18 años han logrado los soviets engañar a un mundo entero, lanzando frases entusiastas sobre la libertad de la mujer en Rusia, prometiendo acabar con la esclavitud, mientras las madres serían obligadas a entregar sus hijos al Estado y el Ejército Rojo, privándolos de una vida familiar burguesa ${ }^{80}$.

Más adelante, cuando la Guerra Mundial favorecía al Eje, la revista Medina lanzó este órdago maniqueo contra todas las antifascistas:

Cada vez el mundo es más sencillo, amigos. Pues se parte en dos mitades perfectas: el Bien y el Mal [...] Desde la maldad pedante y consciente de aquellos amigos de la URSS, a la maldad maravillosa -científica- de los cerebros directores de la propaganda. En medio, amigos, el snobismo, la moda, el cine, la Editorial Cenit, la República, la FUE, las Misiones Pedagógicas, las novelas proletarias, con su pleita escatológica y sus poetas entre invertidos y negroides ${ }^{81}$.

En términos parecidos se expresaría Enrique Jardiel Poncela en la Revista Y de la Mujer Nacional Sindicalista, que dividió a las españolas en cinco colores, teniendo como modelo

78. CDMH, Boletín de Información Antikomintern, 2, 01/12/1937. Ahí también se asegura la destitución de Alexandra Kollontai como embajadora soviética en Estocolmo, ya que su "previsión femenina" le había aconsejado adquirir una casa en Suecia para evitar ser encarcelada, como su homólogo en Helsinki, por no favorecer una operación con el embajador en Moscú.

79. E. Bocanegra, Un espía en la trinchera. Kim Philby en la Guerra Civil española, Barcelona, 2017, 205 y 207.

80. C. Stauffer, "La mujer y el marxismo", Calendario de Sección Femenina de FET y de las JONS, 1939, 284. Véase: W.H. Bowen, Spaniards and Nazi Germany. Collaboration in the New Order, Missouri, 2000, 46.

81. “Niños y mujeres de la URSS”, Medina, I/25, 07/09/1941. 
a las azules del bando nacional franquista. Por el contrario, las verdes serían mujeres fatales provenientes del espectáculo o que vivían de sus encantos personales; las lilas esas estudiantes de la FUE, a las que también se refería Medina como «feministas, pedantes y marisabidillas», republicanas liberales y cosmopolitas «emocionadas de Nuestra Natacha». Después estarían las grises, caracterizadas como muchachas de provincias fracasadas, pretenciosas pero insignificantes y, por último, las rojas propagandistas «lectoras de los rusos por indigestión moscovita crónica»:

Y ante las rojas por feas, contrahechas, patizambas, bizcas o amargadas de la vida, se tomaba un tranvía en marcha. Las snobs, partidarias de Moscú por moda, de las que había ejemplares en todas las clases de la sociedad, eran las más insoportables; la simple conversación con ellas resultaba imposible y acababa uno pensando al alejarse: «ya me lo dirás cuando tus amigos te rebocen a tiros... ${ }^{82}$.

La «cultura de guerra» desplegada en Europa entre 1914-1945 hizo de la «brutalización» y deshumanización del enemigo norma común, cebándose especialmente con las mujeres y caricaturizándolas hasta llegar a lo grotesco ${ }^{83}$. Entre todas las revolucionarias españolas, Margarita Nelken pudo ser la más vilipendiada, desde que arengara a milicianas -como ese Batallón de «Las Infames» citadas por Tono y Mihura en María de la Hoz (1939)- a «pasear» a las familiares de los sublevados. También desde las páginas de la Revista Y, Edgar Neville vio en ella los atributos de la maldad soviética: «Mujer encorsetada y burriciega, pedante y sin encanto femenino, de carne colorada [...] En ella todo era repulsión. Tenía una cursilería emponzoñada [...] se presentía su carne cruda, con varices y una ropa interior violeta ${ }^{84}$.

Las rojas, las no-mujeres desnaturalizadas que renunciaron a su esencia femenina, para alistarse en partidos políticos o trabajar en las fábricas, sucumbirían a un feminismo sobre el que se proyectaron todos los males, «haciéndose más horrendamente hombrunas y convirtiendo los campamentos rojos en burdeles» ${ }^{85}$. De nuevo el Boletín Antikomintern aludía a las obreras rusas como el 39\% de contratados en la industria pesada, no para enorgullecerse de la paridad y las cifras que lanzaban las estadísticas estalinistas, entre 3,3 y 8,4 millones para el periodo 1929-1936, sino para denunciar que trabajaran en un sector tan «masculino»: «Constantemente aumenta el número de mujeres que en el paraíso soviético participan en los más rudos y fatigosos trabajos. Se trata de una fatal consecuencia de las pésimas condiciones económicas del país en general» ${ }^{86}$.

82. E. Jardiel Poncela, “Mujeres verdes, mujeres rojas, mujeres lilas, mujeres grises y mujeres azules”, Y. Revista para la mujer, 1938, 36-37. Sobre la estereotipación de las españolas en el franquismo véase: C. Martín Gaite, Usos amorosos de la postguerra española, Barcelona1994.

83. S. Rodríguez, "Mujeres perversas. La caricaturización femenina como expresión del poder entre la guerra civil y el franquismo", Asparkía, 16, 2005, 177-199.

84. E. Neville, "Margarita Nelken o la maldad", Y. Revista para la mujer, 1938, 12. Citados por F. Sevillano Calero, Rojos. La representación del enemigo en la guerra civil, Madrid, 2007, 109-125.

85. Correo de Mallorca, 09/01/1939.

86. CDMH, Boletín de Información Antikomintern, 2, 01/12/1937, 8-9. 
Como indica Sevillano Calero, hasta Dolores, mito del Partido Comunista y refugiada entonces en Moscú, sería «bestializada cual res bravía» y ridiculizada como «un señor de luto, con barba y bigote, que ganaba tres duros diarios por hacer el papel de La Pasionaria». Tiorras y viragos resentidos, como las calificó Unamuno, serían "científicamente" denostadas por las teorías del psiquiatra franquista Vallejo Nájera, que consideró a todas las milicianas como coimas y prostitutas, llegando a referirse a ellas como «ninfómanas o lesbianas».

La gracia y femineidad de la mujer hispana, convertidas en furia y repulsión oriental... Las que fueron directoras generales, y diputados y presidentas del Comité. Las que incitaron a las demás mujeres a estos actos que nos avergüenzan a todos. El contraste entre la roja y nuestras honestas y cristianas mujeres de zona azul resulta aún más de la monstruosidad de aquéllas ${ }^{87}$.

\section{Conclusión}

La persistencia de actitudes y prácticas patriarcales en la Rusia soviética sería el resultado de la subestimación del papel y la conciencia política que las mujeres desempeñaron en 1917. Estas «parteras de la revolución», como las denominaron Hillyar y McDermid, fueron atraídas por las urgentes necesidades que los bolcheviques debían atender, sin valorar su importancia real. De modo que el triunfo de Octubre estuvo más influenciado por la categoría de clase que la de género, y no llegó a desafiar en profundidad sus tradicionales responsabilidades domésticas. No obstante, el imaginario colectivo europeo quedó profundamente impresionado por la transgresión que significaron las revolucionarias rusas, tanto en la Gran Guerra, como en el Estado comunista.

Si el movimiento obrero español se vio muy influenciado hasta 1922 por lo que sucedía tras los Urales, los Amigos de la Unión Soviética constituyeron en los años treinta una poderosa herramienta de propaganda estalinista, que enmascaraba sus atrocidades con la imagen y estadísticas fabulosas de la mujer rusa: un símbolo de sus conquistas sociales, al mismo nivel que el empleado por la Antikomintern para ridiculizarlas.

La Constitución de 1931 tuvo también en la Ley sobre el Matrimonio, la Familia y la Tutela de 1918 un referente para la igualación de géneros, que no se dramatizaría hasta la Guerra Civil. Fue entonces cuando las antifascistas españolas recuperaron las experiencias combativas de esa genealogía de revolucionarias representadas por el «Batallón de la Muerte» de Maria Bochkareva. Además de empoderarse con las armas y las responsabilidades de retaguardia, muchas españolas se mostraron por primera vez liberadas de atavismos morales, lo que removería los temores más profundos del tradicionalismo patrio. Desde entonces fue misión del centinela de Occidente interceptarlas, recurriendo a las listas negras y «liberando» a las españolas «del taller y de la fábrica» donde se curtieron las obreras bolcheviques.

87. A. Vallejo Nájera, La locura y la guerra. Valladolid, 1937, 225. Véase también: J. Morales, Propaganda anticomunista en el primer franquismo a través de NO-DO (1943-1955), Sevilla, 2011. 